\title{
Critical Thinking, Writing Performance and Topic Familiarity of Indonesian EFL Learners
}

\author{
Rohmani N. Indah \\ UIN Maulana Malik Ibrahim, Malang, Indonesia
}

\begin{abstract}
This study seeks the evidence for the best pattern of relationship among critical thinking, writing performance and topic familiarity of EFL students at an Islamic university in Indonesia. Understanding the patterns of relationship is important to develop teaching syllabus, materials and evaluation method for teaching critical writing class. It employs ex-post-facto design to English department students. The instruments used were writing prompts and rubrics for assessing the observed skills namely critical thinking, writing performance and topic familiarity. Path analysis was used to figure out the pattern of relationship. The verified patterns of relationship show that on student initiated topic, critical thinking skills are triggered by topic familiarity and can be mediated by writing performance. Topic familiarity also has direct contribution toward critical thinking skills on student initiated topic. Similarly, on teacher initiated topic, critical thinking skills are supported by topic familiarity and can be mediated by writing performance as well. However, topic familiarity of teacher initiated topic does not have direct contribution toward critical thinking skills. The finding also indicates that the verified path model serves as the best pattern and can be used as a framework to predict the success of the student's critical thinking skills.
\end{abstract}

Index Terms — critical thinking, writing performance, topic familiarity, EFL, path analysis

\section{INTRODUCTION}

Critical thinking has become a very important educational goal over the last two decades. Students need to have 'good thinking' skills by using reasoning and logic focusing on what to believe or do based on the mechanism such as conducting conceptual and argument analyses for problem solving and decision making (Pithers \& Soden, 2001). Therefore, educators believe that this competence constitutes an important cognitive skill to be acquired.

Critical thinking in Indonesian context becomes buzzword especially after Reform Era in 1998 which was characterized by massive demonstration in which the freedom to express one's thought has become a crucial start to build critical thinkers (Emilia, 2010). Indonesia needs more figures of critical thinkers like Sukarno (the first president), Abdurrahman Wahid (the third president), and others. Therefore today developing critical thinking has also emerged in Indonesian education. Referring to the international benchmark of education, the $3 \mathrm{R}$ basic literacy (reading, writing, arithmetic) seems to be insufficient today. It needs to be completed into 4R basic competences (reading, writing, arithmetic, and reasoning), so that learners are equipped with skills needed to support their current and future life economically, socially and culturally (Hayat \& Yusuf, 2010). This issue has become more significant particularly in facing the more challenging world.

Critical thinking skills do not stand alone as these skills tail another skill namely language skills. Becoming critical thinker is characterized by effective communication (Paul \& Elder, 2008). This means that language clarity or more generally linguistic component is a crucial part of critical thinking which can be reflected through both speaking and writing. In other words, measuring critical thinking can be done through several ways involving speaking and writing competencies. This study concerns the critical thinking measured through writing in particular.

Among other types of writing, argumentative writing is considered the writing mode that best reflects student's critical thinking. In expository writing for instance, idea development can be done through classification, cause and effect, procedural or analytic exposition involving logic as the basic of critical thinking. However, in this type of writing there is no refutation as what required in argumentative writing to defend the claim. Recognizing opposing argument and making counter argument belong to elements of argumentative writing. Because arguments deal with probabilities, they must be qualified to convince readers (Hillocks, 2011). Therefore, in this study argumentative writing is chosen to assess student's critical thinking skills.

Student's argumentative writing can be used to measure not only the writing performance but also critical thinking skills. Student's writing performance is mostly indicated by the quality of the writing product, which focuses on its clarity, originality and correctness (Rahim et al., 2008). The critical thinking skills can be assessed on the elements which are reflected from the main aspects namely argument, evidence, recognition of opposition, refutation, conclusion, references, and fallacies (Stapleton, 2001). Argument or writer's view point on a topic is presented in the form of claims supported by a reason. Evidence constitutes statements or assertions which serve to strengthen the argument. Recognition of opposition refers to the identification of statements that run counter or offering alternative interpretations to those expressed in the claim. Refutation deals with the statement that the opposing viewpoints are 
inadequate in some ways. A conclusion is a statement or series of statements in which a writer sets out what s/he wants the reader to believe. References are related to the use of citation to support the claim. Fallacies are errors in reasoning which do not support the claim. The last element is not always reflected in the writing.

The concern on critical thinking in the Indonesian context still needs exploration. A case study analyzing student's essays show that the problem is not on critical thinking itself but the related factors especially language and subject matter mastery (Samanhudi \& Sampurna, 2010). Teachers, accordingly, need to provide suitable materials to enhance critical thinking (Sepriani, 2010) as well as to apply various uses of teacher's questions which can encourage the development of critical thinking (Yumarnamto \& Widiyanto, 2005). Meanwhile, teaching critical thinking in Indonesia may involve some cultural constraints (Kameo, 2007). Hence, there is still inadequate empirical data on the critical thinking and critical pedagogy in Indonesian context. Accordingly, this study concerns with critical thinking in relation with other variables namely topic familiarity and writing performance.

Writing course is a part of the teaching of critical thinking skill. In the writing process, learners develop their critical thinking skills involved in generating ideas by using problem-solving process employing a range of cognitive and linguistic skills. These will lead learners to identify a purpose, to produce and shape ideas and to refine expression (White, 1995). A successful writing class should end with the development of critical thinking which is initiated by finding the learner's interest or expertise (Indah, 2009) and is geared from collaborative writing activities (Indah, 2010).

In this study, writing performance is assessed based on the fulfillment of the descriptors referring to the criteria of proficient writers. The competence to express ideas on written form requires effective writing skills in developing a topic to be knowledgeable, sequencing ideas logically, expressing meaning in correct diction, constructing sentences and using writing conventions. These writing skills refer to the criteria in evaluating composition namely content, organization, vocabulary, language use and mechanics (Jacobs et al., 1981). The effective writing skills contribute to the better critical thinking skills.

In writing class, critical thinking is an inseparable aspect as identified by the writer during her eight year experience in teaching writing. She found that although the students had low writing performance, they tried to communicate their critical thinking skills through some ways such as writing in their first language or presenting their ideas in the teacherstudent conference in pre-writing stage by using code-switch. Therefore, the writer believes that these skills need to be taught implicitly as shown by two preliminary studies done in English department at Maulana Malik Ibrahim State Islamic University. The first study intended to raise the critical thinking awareness through interest based writing publication. The students were involved in the collaborative writing activities which require the skills of evaluating claims of other writers both in class discussion and student-teacher conference. The students performed better claim as the result of the development of critical thinking skills as they are responsible for publishing their argumentative writing in the form of mini magazine. Meanwhile, the second study was carried out to see the ability of the students in analyzing their own essay and constructing a reflective writing in English and Indonesian. The results show that the students were able to reflect their critical thinking in both languages although there were some constraints in stating knowledge, making inference and giving evidence. Further, she assumed that it is the topic familiarity affecting the quality of student's writing and critical thinking. However, it needs more exploration on which one between student or teacher initiated topic affecting more on the quality of student's writing and critical thinking.

In this study, the knowledge of certain topic to be developed in the form of argumentative essay is categorized into two kinds namely student initiated topic and teacher initiated topic. The former is regarded to be more familiar than the latter as the topic to write is chosen by the students based on their interest and conceptual knowledge. In writing classes, teacher initiated topic derives from general topic which is usually obtained through brainstorming as pre-writing activity. In this study, the topic provided by the teacher has been proven to be unfamiliar which has been experimented in the pilot study. Accordingly, for the sake of the research, teacher initiated topic is regarded as unfamiliar topic and that does not mean that all of the topics initiated by writing teachers are unfamiliar to students.

The starting point of this study is to portray the patterns of relationship among the hypothesized variables contributing to student's critical thinking skills. The objectives of the research are to examine (1) whether student's topic familiarity on different topics is related to their writing performance and critical thinking skills, (2) whether the better topic familiarity on student initiated topic the better their writing performance and critical thinking skills will be, and (3) whether the better topic familiarity on teacher initiated topic the better their writing performance and critical thinking skills will be.

\section{LITERATURE REVIEW}

The word 'critical' originates from kriticos or discerning judgment and kriterion meaning standards which etymologically implies the development of discerning judgment based on standards (Pithers \& Soden, 2001). In Webster's World University Dictionary (Taylor, 1965), critical thinking equals to careful analysis and judgment which imply an attempt at objective judgment so as to determine both merits and faults. The competence in developing judgment based on standard becomes the point to measure that one is called a critical thinker.

This study explores the critical thinking and writing. Regarding the relationship between both, the Sapir-Whorf hypothesis (1956 in Errihani, 2012) is suggestive in the context of English as Foreign Language as it contends that cognitive activity is determined by language. The cognitive activity can be reflected in written text and later be 
understood well by the audience determined by the strength of the language (Vallis, 2010). As the consequence, the main concern of second language (L2) writers is primarily on linguistics as noted by Errihani (2012). Therefore, the reflection of critical thinking follows their linguistic skill represented by their writing and topic familiarity reflecting the background knowledge.

Background knowledge supporting reading skill is crucial for effective writing performance. There are five knowledge should be acquired by L2 writers. They are content knowledge, system knowledge, process knowledge, genre knowledge, and context knowledge. Content knowledge consists of the ideas and concepts in the topic area the text will address. System knowledge is related to syntax, lexis, appropriate formal conventions needed in creating the texts. Process knowledge deals with the ways to prepare and carry out a writing task. Genre knowledge is about the communicative purposes of the genre and its value in particular context. And context knowledge is linked to the readers' expectations, cultural preferences, and related texts (Hyland, 2003). By acquiring the knowledge, L2 writers can express their ideas in an appropriate and convincing way.

The issue on the relation between reading, writing and critical thinking becomes the concern of Kobayashi and Rinnert (2008). Based on the topics which are familiar to students, on the choice to live at home or alone and to travel with a group or alone, students were asked to write in Japanese and English. The results show that topic familiarity supports the student's ease in writing. In other words, it reinforces the student's tendency to apply the meta-knowledge they had acquired to their L1 and L2 essay writing although they tend to write differently in both languages. The students tend to write expository in Japanese and argumentation in English, but their essays show better idea organization in English.

Topic familiarity that influences reading skill also plays a role to enable writers shaping their rhetoric. Because of their background knowledge, the writer's critical thinking is expressed differently based on their problematization strategy in writing argumentative essays. As investigated by Mei (2006), high rated and low rated essays perform differently in discussing problematization of issues. Writers of high rated essay or students with high writing performance indicate a more strategic and appropriate use of evaluative resources to create clear lines of contrast positions. Whereas, low rated essays are characterized by a weaker sense of contrast in stance partly because the problematization strategy is lacking. In this case, the sources of dispute are not clarified resulting in a sense of a lack of authenticity to the potential debate resulting in a 'simplistic approach to an argumentative topic they raise.

\section{METHOD}

This study employs a correlational design involving path analysis. As the study investigates the critical thinking skills as reflected in student's argumentative writing and there is no effort made by the researcher to manipulate the characteristics of any variables involved, this study is also called an ex-post-facto research. Based on the dimension of time, the design of this study is a cross-sectional one. The assessments of writing, topic familiarity and critical thinking skills are done only at the certain point of time of the data collection when the present study is conducted.

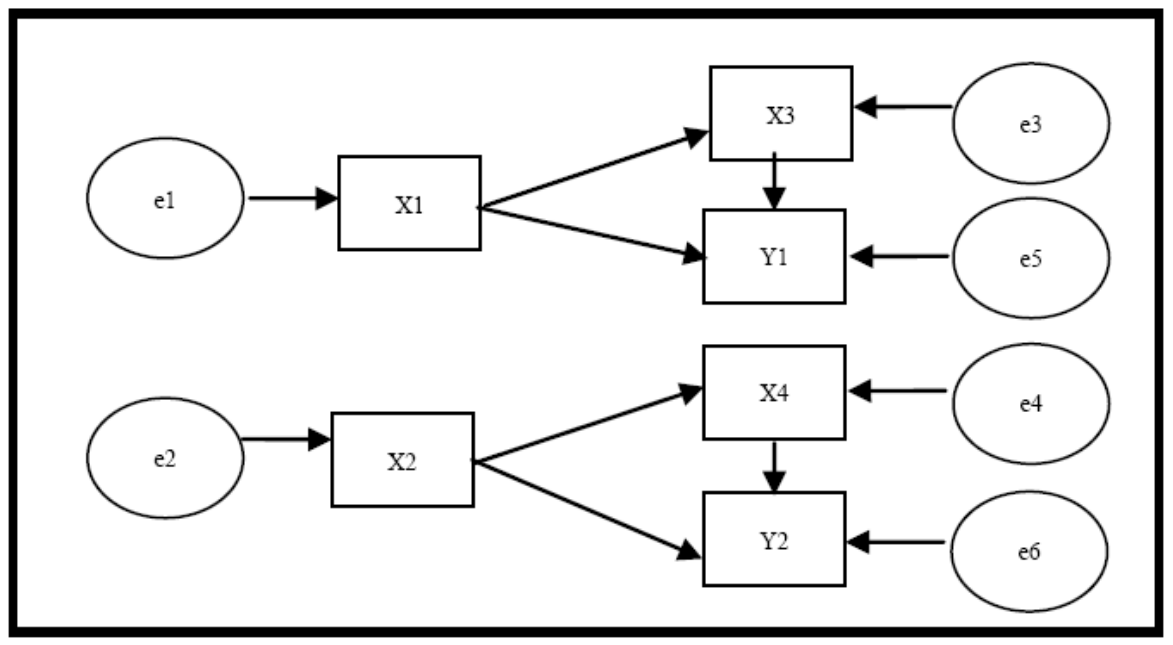

X1: Topic familiarity of student initiated topic (exogenous variable)

X2: Topic familiarity of teacher initiated topic (exogenous variable)

$\mathrm{X} 3$ : Writing performance in student initiated topic (endogenous variable)

$\mathrm{X} 4$ : Writing performance in teacher initiated topic (endogenous variable)

Y1: Critical thinking skills in student initiated topic (endogenous variable)

Y2: Critical thinking skills in teacher initiated topic (endogenous variable)

e: Residual or errors

Figure 1 Estimated Path Model

The target population of this study is English department students of Maulana Malik Ibrahim University who had passed courses on paragraph writing and academic writing. This means that administratively they have reached 
approximately post-intermediate to pre-advanced level of writing. Those taking critical writing course were taken as the sample with the total number 121 students, aged 20-22 consisting of 48 males and 73 females.

Some research instruments were employed to collect the data. They are: (1) writing prompts used to elicit data on student's argumentative writing on student initiated topic (or on free topic) and on teacher initiated topic (that is on "critical thinking"), (2) rubric for assessing topic familiarity through mind map which is adapted from Franker (2011) to identify the student's familiarity on certain topic seen from the arrangement of concepts, links and linking lines, content, and text, (3) rubric for assessing writing performance using ESL Composition Profile (Jacobs et al., 1981), and (4) rubric for assessing critical thinking skills adapted from Stapleton (2001).

The data were collected by administering the tests to gain the scores on writing, reading and critical thinking skills. However, the prompts were informed earlier to the students as students need to have the opportunity to prepare the content in advance of the writing because of the difficulties to manage the linguistic demands as second language writers and to allow students to demonstrate their best writing.

\section{RESULTS}

In writing essays, students perform differently based on the topics given. Students at the first test write an essay based on their preference or which is called student initiated topic. Then, they write another essay based on teacher initiated topic. The different performance is summarized in Table 1 on the three observed aspects namely critical thinking skills, writing performance and topic familiarity.

TABLE 1

DESCRIPTIVE STATISTICS OF STUDENT's CRITICAL THINKING SKILLS, WRITING PERFORMANCE AND TOPIC FAMILIARITY

\begin{tabular}{lllllll}
\hline Measures & $\begin{array}{l}\text { Critical } \\
\text { Thinking } \\
\text { Student } \\
\text { Topic }\end{array}$ & $\begin{array}{l}\text { Critical } \\
\text { Thinking } \\
\text { Teacher } \\
\text { Topic }\end{array}$ & $\begin{array}{l}\text { Writing } \\
\text { Student } \\
\text { Topic }\end{array}$ & $\begin{array}{l}\text { Writing } \\
\text { Teacher } \\
\text { Topic }\end{array}$ & $\begin{array}{l}\text { Topic } \\
\text { Familiarity } \\
\text { Student } \\
\text { Topic }\end{array}$ & $\begin{array}{l}\text { Topic } \\
\text { Familiarity } \\
\text { Teacher } \\
\text { Topic }\end{array}$ \\
\hline $\mathrm{N}$ & 100 & 100 & 100 & 100 & 100 & 100 \\
Mean & 17.485 & 18.570 & 78.940 & 83.290 & 40.675 & 37.925 \\
Median & 17.500 & 18.750 & 80.000 & 84.000 & 40.000 & 40.000 \\
Mode & 16.5 & 25.0 & 81.0 & 90.0 & 40.0 & 40.0 \\
SD & 3.8524 & 4.3583 & 8.7031 & 8.0004 & 10.6414 & 11.6453 \\
Range & 15.0 & 15.0 & 43.0 & 38.5 & 40.0 & 40.0 \\
Max & 25.0 & 25.0 & 94.0 & 98.0 & 60.0 & 60.0 \\
Min & 10.0 & 10.0 & 51.0 & 59.5 & 20.0 & 20.0 \\
\hline
\end{tabular}

The ability to show critical thinking skills is higher in teacher initiated topic. However, the range of score is low, which means that the dispersion of score is not too far in both topics. On student initiated topic, the writing performance is lower than the teacher initiated topic. The range of the writing score is lower than the possible range which means that the dispersion is not too far in both topics. Meanwhile, on student initiated topic the students can elaborate more ideas compared to their topic familiarity on teacher initiated topic shown by the higher mean. The variation of the topic familiarity is larger in teacher initiated topic.

Based on scores showing the students skills on critical thinking, writing and reading, the path model is then examined. Using AMOS application, the regression weight obtained is as the following.

TABLE 2

REGRESSION WEIGHT

\begin{tabular}{lllcc}
\hline Paths & Association & Estimate & P & Label \\
\hline $\mathrm{X} 1 \rightarrow \mathrm{X} 3$ & Topic familiarity on Student Topic $\rightarrow$ Writing on Student Topic & .388 & $* * *$ & Significant \\
\hline $\mathrm{X} 1 \rightarrow \mathrm{Y} 1$ & Topic familiarity on Student Topic $\rightarrow$ CT skills of Student Topic & .272 & .003 & Significant \\
\hline $\mathrm{X} 3 \rightarrow \mathrm{Y} 1$ & Writing on Student Topic $\rightarrow$ CT skills of Student Topic & .397 & $* * *$ & Significant \\
\hline $\mathrm{X} 2 \rightarrow \mathrm{X} 4$ & Topic familiarity on Teacher Topic $\rightarrow$ Writing on Teacher Topic & .212 & .008 & Significant \\
\hline $\mathrm{X} 2 \rightarrow \mathrm{Y} 2$ & Topic familiarity on Teacher Topic $\rightarrow$ CT skills of Teacher Topic & .078 & .326 & Not significant \\
\hline $\mathrm{X} 4 \rightarrow \mathrm{Y} 2$ & Writing on Teacher Topic $\rightarrow$ CT skills of Teacher Topic & .447 & $* * *$ & Significant \\
\hline
\end{tabular}

Table 2 shows the association between the independent variables and the dependent variables. The percentage of the contribution of the independent variables toward the dependent variables is represented by the determining coefficient as shown in Table 3 below:

TABLE 3

SQUARED MULTIPLE CORRELATION

\begin{tabular}{|c|c|c|c|}
\hline Paths & Associations & $\begin{array}{l}\text { Determining } \\
\text { Coefficient }\left(\mathrm{R}^{2}\right)\end{array}$ & Error \\
\hline $\mathrm{X} 1 \rightarrow \mathrm{X} 3$ & Topic familiarity on Student Topic $\rightarrow$ Writing on Student Topic & 0.150 & .841 \\
\hline $\mathrm{X} 2 \rightarrow \mathrm{X} 4$ & Topic familiarity on Teacher Topic $\rightarrow$ Writing on Teacher Topic & 0.377 & .591 \\
\hline $\mathrm{X} 1 \mathrm{X} 3 \rightarrow \mathrm{Y} 1$ & Topic familiarity \& Writing on Student Topic $\rightarrow$ CT skills of Student Topic & 0.315 & 678 \\
\hline $\mathrm{X} 2 \mathrm{X} 4 \rightarrow \mathrm{Y} 2$ & Topic familiarity \& Writing on Teacher Topic $\rightarrow$ CT skills of Teacher Topic & 0.430 & .538 \\
\hline
\end{tabular}


Among the six possible paths as illustrated in the estimated path model, the result of the computation using path analysis shows five significant relationships. As mentioned by the regression weight in Table 2, there is one path which is insignificant that is on the association between topic familiarity of teacher initiated topic and critical thinking skills in teacher initiated topic. The summary of the above analysis is shown in the empirical path model in Figure 2 . In the model the insignificant path is shown by the omitted arrow linking the topic familiarity of teacher initiated topic and the critical thinking skills in teacher initiated topic.

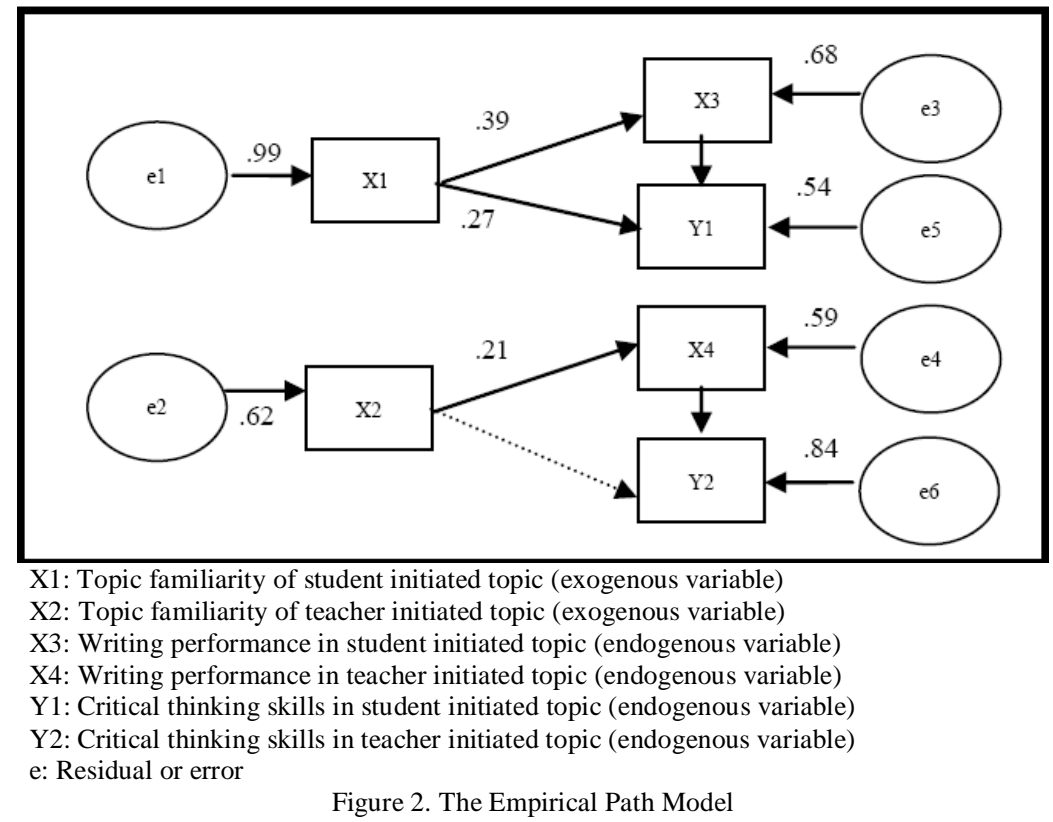

Based on the computation of coefficient of tolerance, the total determining coefficient of the path model is 0.7900 which means that the path diagram explains $79 \%$ information contained in the data. The rest $21 \%$ are not explainable by the path or in other words are affected by other variables not mentioned in this study. It may further indicate that this path can be a good model to predict the critical thinking skills. The correlation of the path model is very strong. Finally, it is clear that the alternative hypothesis is retained as there is significant, positive and very strong correlation between the empirical path model and the variables of critical thinking, writing performance and topic familiarity.

\section{DISCUSSION}

The analysis of the relationship among the three variables in this study covers two sections, on student initiated topic and on teacher initiated topic. On the path between the topic familiarity and writing performance in the student-initiated topic, the correlation is significant and positive. The strength of the correlation is moderate at the value 0.388 . It can be inferred that the better topic familiarity the students in student initiated topic, the higher their writing performance will be.

On the path between the writing and critical thinking skills in student initiated topic, the positive and statistically significant correlation is found. The strength of the correlation is moderate at the value 0.397 . It can be inferred that the higher the student's writing performance in student initiated topic, the better reflection of their critical thinking skills will be.

The contribution of writing performance toward critical thinking skills seems to indicate that the result of the writing namely the learner's essay is connected with cognitive domain (Overbaugh \& Schultz, 2008) shown by the reflection of critical thinking elements. This means that the quality of the essay writing involves the development of the cognitive domain reflected in the critical thinking skills.

That writing performance undeniably associated with critical thinking seems to support Wade (1995). She postulates that the writing skill developed through a set of short writing assignment can tap the essential stages of critical thinking and creative thought. It may further denote that improving writing could guide students to shape the way they construct thought and to become more critical thinkers.

The path between writing performance and critical thinking skills which is significant is also reported in an experimental foods course at University of Hawaii as studied by Iwaoka and Crosseti (2008). The increase of the student's skills in writing journal was followed by a better competence in reflecting their learning, developing critical reasoning and analyzing personal values. These activities required the practice of multiple cognitive skills which may yield in the development of critical thinking skills.

On teachers initiated topic, different result is found. The finding shows significant path on the association between the writing performance and topic familiarity in the teacher-initiated topic. It indicates that the better topic familiarity 
on teacher initiated topic, the higher writing performance will be. This finding seems to support what Delaney (2008) found that there is positive yet weak correlation between student's performance or critical thinking in writing with teacher initiated topic and their writing performance. Similarly, in this study the strength of the correlation is also weak at the value 0.212. Delaney's study was done in the context of EFL and ESL learning which shows similar correlation to the EFL context in this study.

The significant and positive relationship between topic familiarity and writing performance in teacher initiated topic is also proven by Bacha (2010) who found that topic familiarity of teacher initiated topic supports building the context for better performance in writing argumentative essays done by L1 Arabic students in EFL environment at Lebanese American University, Lebanon. Furthermore, the better reading comprehension is helpful to improve writing performance. This is also asserted by Cahyono (1992) who found that in EFL writing context the comprehension drawn in the brain pattern happened to be significant to help students write better in their content-based summary writing. Therefore, these studies share the same context as well as finding with the current research on the postulate that the more familiar the students with a topic the better writing produced will be.

The significant and positive correlation also exists in the path between the writing and critical thinking skills in teacher initiated topic. The strength of the correlation is strong at the value 0.447 . It indicates that the higher the student's writing performance in teacher initiated topic, the better reflection of their critical thinking skills will be.

The better writing performance is significant to promote the critical thinking as proven in this study which is in line with the finding of Oliver-Hoyo (2003). In her study, the improvement in student's writing is shaped by feedback given during the introductory college chemistry course. She monitors and assesses the implementation of critical thinking skills through the rubrics set to see whether certain standard has been achieved. Her research shares similar point of view with this study on the importance of using rubric as a valuable measuring tool of critical thinking.

The dominance of writing to improve critical thinking skill seems to support the theoretical framework postulated by Quitadamo and Kurtz (2007). Their study in a general education biology course in a state university at Pacific Northwest shows the improvement of critical thinking performance of students who experienced a laboratory writing treatment compared with those who experienced traditional quiz-based laboratory. In addition, analysis and inference skills increased significantly in the writing group but not in the non-writing group. Thus, writing skill significantly affects critical thinking performance as the building the ideas through writing also include some aspects of critical thinking skills.

On the association between topic familiarity and critical thinking skills in teacher initiated topic, there is no significant correlation found. The relationship occurs due to chance or only because of sampling error. Therefore, this path is considered noncontributing in the estimated model. This finding shares similar viewpoint with the theoretical framework postulated by Delaney (2008). She found that by using teacher initiated topic, the ESL and EFL students in Venezuela perform different critical thinking skills. The analytic writing or response essays were found to engage learners in more critical thinking than the summary writing which requires identifying important information in the source text given by the teacher. In addition, the student's performance or critical thinking in writing with teacher initiated topic is weakly correlated with their writing performance. It signifies that the student's performance in teacher initiated topic is not as predictable as in student initiated topic. This may further indicate that using student initiated topic students can prepare or plan better to improve their performance in writing to reflect critical thinking skills. However as the finding does not confirm with more evidence from previous research, there is a need for more studies that explore the relationship between reading and critical thinking skills in teacher initiated topic.

The finding in this study stating that there is no significant correlation between topic familiarity and critical thinking skills in teacher topic is relevant to the specific conception of critical thinking. Critical thinking is context specific involving background knowledge on certain subject matter only and in another (Emilia, 2010). It means that when the student's specialized knowledge of the topic to write is insufficient then the critical thinking cannot be identified well.

The teacher initiated topic in this study is on the issue relevant with how to improve reasoning ability. It deals with the teacher expectation. The students might fail to reach the teacher's expectation both in describing knowledge and reflecting reasoning ability. The failure to meet the teacher's expectation is because of some factors not identified in this study. However, one of the possible factors identified is the weakness of the writing prompt.

Regarding the empirical evidence on teacher initiated topic showing weak correlation, it signifies the limitation of this study that deal with the assessment instruments, especially those testing critical thinking. While the instrument selected was carefully chosen from among all available published inventories and seemed most appropriate for the study, there is still much work to be done to refine and to improve existing instrument. In addition, developing additional instruments that adequately measure student's gains in critical thinking skills and dispositions is needed.

Another limitation of the analysis in this study deals with the measurement of student's writing product in the form of argumentative essay. Yet, it did not address the flow of mental activities underlying student's critical thinking during writing process. Thinking aloud protocols are not used to measure the stream of thought contents students engaged in while composing.

\section{CONCLUSION}


The verified patterns of relationship show that on student initiated topic, critical thinking skills are initiated by topic familiarity and can be mediated by writing performance. Topic familiarity also has direct contribution toward critical thinking skills on student initiated topic. Whereas, on teacher initiated topic, critical thinking skills are initiated by topic familiarity and can be mediated by writing performance as well. The path model serves as the best pattern and can be used as a framework to predict the success of the student's critical thinking skills. The writing performances in both student and teacher initiated topic record the highest contribution toward critical thinking skills. It means that regardless the type of topic chosen the higher the student's writing performance the better reflection of their critical thinking skills will be. Because the student's writing performance is followed by the betterment of their critical thinking skills, writing performance is proven to be a good predictor of student's critical thinking skills.

On student initiated topic, the better reading on their topic, the higher their writing performance will be. It implies that the specialized knowledge obtained in the reading process may influence the quality of the essay as the product of writing stage. The finding also signifies that the higher the student's writing performance, the better reflection of their critical thinking skills will be. Furthermore, the better student's reading skill on their topic also entails better reflection of their critical thinking skills. It shows that the recalling of information through reading for understanding ways of thinking and writing stimulate the reproduction of knowledge.

On teacher initiated topic, the better skill in reading with the given topic, the higher student's writing performance will be. This finding shows that the student's ease in writing and their better writing performance are affected by the comprehension of the topic to write. The finding also indicates that the higher the student's writing skill, the better reflection of their critical thinking skills will be.

As this study examined the patterns of relationship among critical thinking, writing performance and topic familiarity, more empirical finding is needed to explore with the goal of a broad, unified concept of critical thinking skills. The relationship between the reflection of critical thinking in everyday reasoning and that in various fields of expertise also needs further research. In addition, training Indonesian students especially those studying in Islamic universities to think critically can be done implicitly through critical writing course. Once the student's linguistic aptitude is shaped, the reflection of critical thinking skills will follow. The skills such as analyzing complex issues and generating solutions through arguments, making connections and transferring insights to new contexts, and developing standards for decision making, are necessary to succeed in academic and in society.

\section{REFERENCES}

[1] Bacha, N. N. (2010). Teaching the academic argument in a university EFL environment. Journal of English for Academic Purposes, 9, 229-241. http://dx.doi.org/10.1016/j.jeap. 2010.05.001.

[2] Cahyono, B. Y. (1992). Development and application of content-based summarizing technique in reading instruction. Thesis submitted to State University of Malang.

[3] Delaney, Y. A. (2008). Investigating the reading-to-write construct. Journal of English for Academic Purposes, 7, 140-150. doi:10.1080/00405841.2011.558435.

[4] Emilia, E. (2010). Teaching writing: developing critical learners. Bandung; Rizqi Press.

[5] Errihani, M. (2012). Critical thinking and the language factor: the case for the English language learner. Arab World English Journal, 3 (3), 4-17.

[6] Franker, https://www2.uwstout.edu/content/profdev/rubrics/inspirationrubric.html (accessed 11/12/2014).

[7] Hayat, B. \& Yusuf, S. (2010). Benchmark internasional mutu pendidikan. Jakarta: Bumi Aksara.

[8] Hillocks, G. (2011). Teaching argument writing: grade 6-12. Portsmouth: Heinemann.

[9] Hyland, K. (2003). Second language writing. Cambridge: Cambridge University Press

[10] Indah, R. N. (2009.) Developing students' critical thinking awareness through interest-based claims writing publication. TEFLIN 56th Responding to Global Challenges through Quality English Language Teaching. Malang: UIN.

[11] Indah, R. N. (2010). Discovering student's expertise to augment claim quality in writing class at UIN Maliki Malang. National Conference in Language and Literature: Global Perspective in Literature and Language Teaching. Malang: Ma Chung University.

[12] Iwaoka, W. T. \& Crosetti, L. M. (2008). Using academic journals to help students learn subject matter content, develop and practice critical reasoning skills, and reflect on personal values in food science and human nutrition classes. Journal of Food and Science Education, 7, 19-29.

[13] Jacobs, H. L., Zinkgraf, S. A., Wormuth, D. R., Harfiel, V. F. and Hughey, J. B. (1981). Testing ESL composition: practical approach. Rowley: Newbury House.

[14] Kameo, R. M. (2007). Critical thinking in the classroom: some cultural constraints. English Edu, 7 (1), 1-13.

[15] Kobayashi, H. \& Rinnert, C. (2008). Task response and text construction across L1 and L2 writing. Journal of Second Language Writing. 17, 7-29.

[16] Mei, W. S. (2006). Creating a contrastive rhetorical stance: investigating the strategy of problematization in students' argumentation. RELC Journal, 37 (3), 329-353. doi: 10.1177/0033688206071316.

[17] Oliver-Hoyo, M. T. (2003). Designing a writing assignment to promote the use of critical thinking skills in an introductory chemistry course. Journal of Chemical Education, 80 (8), 899-903. DOI: 10.1021/ed080p899.

[18] Overbaugh, R. C. \& Schultz, L. (2008). Bloom's taxonomy. http://ww2.odu.edu/educ/roverbau/Bloom/blooms_taxonomy.htm (accessed 12/4/2013). 
[19] Paul, R. \& Elder, L. (2008). The miniature guide to critical thinking concepts and tools, foundation for critical thinking press. https://www.criticalthinking.org/files/Concepts_Tools.pdf (accessed 3/7/2014).

[20] Pithers, R. T. \& Soden, R. (2001). Critical thinking in education: a review. Educational Research, 42 (3), 237-249. doi: $10.1080 / 001318800440579$.

[21] Quitadamo, I. J. \& Kurtz, M. J. (2007). Using writing to increase critical thinking performance in general education biology. CBE-Life Sciences Education, 6, 140-154. doi: 10.1187/cbe.06-11-0203.

[22] Rahim, P. R., Abdullah, S. \& Ishak, N. R. (2008). Collaborative writing techniques as a tool in promoting writing skill to tertiary level students. 6th Asia TEFL Globalizing Asia: The Role of ELT. Denpasar: AsiaTEFL.

[23] Samanhudi, U. \& Sampurna, P. (2010). Researching students' critical thinking in EFL writing class (a case study in English education department, Untirta). TEFLIN 57th Revitalizing Professionalism in ELT as a Response to Globalized World. Bandung: Indonesia University of Education.

[24] Stapleton, P. (2001). Assessing critical thinking in the Japanese university students. Written Communication, 18 (4), $506-548$. doi: $10.1177 / 0741088301018004004$.

[25] Taylor, R. C. (1965). Webster's world university dictionary. Washington: Webster.

[26] Vallis, G. L. (2010). Reason to Write: Applying Critical Thinking to Academic Writing. Charlotte: Kona.

[27] Wade, C. (1995). Using writing to develop and assess critical thinking. Teaching of Psychology, 22 (1), $24-28$. doi:10.1207/s15328023top2201_8.

[28] White, R. V. (1995). New ways in teaching writing. Bloomington: Pantagraph.

[29] Yumarnamto, M. \& Widiyanto, Y. M. (2005). Promoting critical thinking in EFL classrooms. 53rd TEFLIN Promoting Critical Thinking in EFL Classrooms. Yogyakarta.

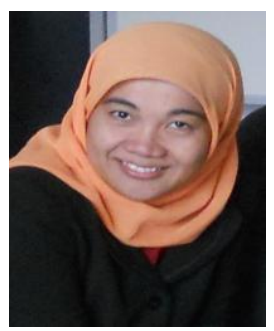

Rohmani N. Indah is lecturer in Humanities Faculty of State Islamic University Maualana Malik Ibrahim, Malang-Indonesia. She earned her doctorate in English Language Teaching from State University of Malang, East Java, Indonesia. Her research concerns on psycholinguistics, writing skills, critical thinking, and autism. She is the editorial chief of El Harakah Journal on Islamic Culture at UIN Malang. 